University of Nebraska - Lincoln

DigitalCommons@University of Nebraska - Lincoln

USDA National Wildlife Research Center - Staff Publications
U.S. Department of Agriculture: Animal and Plant Health Inspection Service

2009

\title{
A review of mitigation measures for reducing wildlife mortality on roadways
}

David J. Glista

Indiana Department of Transportation,

Travis L. DeVault

USDA/APHIS/WS National Wildlife Research Center, Travis.L.DeVault@aphis.usda.gov

J. Andrew DeWoody

Purdue University

Follow this and additional works at: https://digitalcommons.unl.edu/icwdm_usdanwrc

Part of the Environmental Sciences Commons

Glista, David J.; DeVault, Travis L.; and DeWoody, J. Andrew, "A review of mitigation measures for reducing wildlife mortality on roadways" (2009). USDA National Wildlife Research Center - Staff Publications. 846. https://digitalcommons.unl.edu/icwdm_usdanwrc/846

This Article is brought to you for free and open access by the U.S. Department of Agriculture: Animal and Plant Health Inspection Service at DigitalCommons@University of Nebraska - Lincoln. It has been accepted for inclusion in USDA National Wildlife Research Center - Staff Publications by an authorized administrator of DigitalCommons@University of Nebraska - Lincoln. 
Review

\title{
A review of mitigation measures for reducing wildlife mortality on roadways
}

\author{
David J. Glista ${ }^{\mathrm{a}}$, Travis L. DeVault ${ }^{\mathrm{b}, *}$, J. Andrew DeWoody ${ }^{\mathrm{c}}$ \\ a Indiana Department of Transportation, Office of Environmental Services, Ecology Unit, 100 North Senate Avenue, IGCN, Room N642, Indianapolis, IN 46204, USA \\ ${ }^{\mathrm{b}}$ United States Department of Agriculture, Wildlife Services, National Wildlife Research Center, 5757 Sneller Road, Brewerton, NY 13029, USA \\ ${ }^{\mathrm{c}}$ Department of Forestry and Natural Resources, Purdue University, 195 Marsteller Street, West Lafayette, IN 47907, USA
}

\section{A R T I C L E I N F O}

\section{Article history:}

Received 9 October 2007

Received in revised form 15 April 2008

Accepted 3 November 2008

Available online 17 December 2008

\section{Keywords:}

Mitigation

Wildlife

Roads

Habitat

Movements

Mortality

\begin{abstract}
A B S T R A C T
A growing literature in the field of road ecology suggests that vehicle/wildlife collisions are important to biologists and transportation officials alike. Roads can affect the quality and quantity of available wildlife habitat, most notably through fragmentation. Likewise, vehicular traffic on roads can be direct sources of wildlife mortality and in some instances, can be catastrophic to populations. Thus, connectivity of habitat and permeability of road systems are important factors to consider when developing road mortality mitigation systems. There are a variety of approaches that can be used to reduce the effects of roads and road mortality on wildlife populations. Here, we briefly review wildlife-crossing structures, summarize previous wildlife road mortality mitigation studies, describe common mitigation measures, and discuss factors that influence the overall effectiveness of mitigation strategies. Because there are very few road mortality studies "before" and "after" the installation of wildlife-crossing structures, their efficiency is nearly impossible to evaluate. However, simple and relatively inexpensive measures reviewed herein can almost certainly reduce the number of collisions between wildlife and automobiles.
\end{abstract}

Published by Elsevier B.V.

\section{Contents}

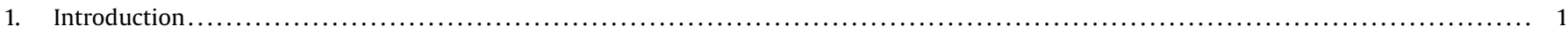

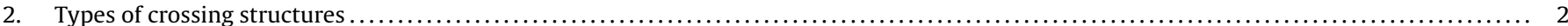

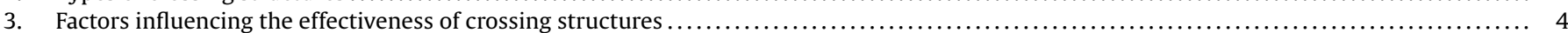

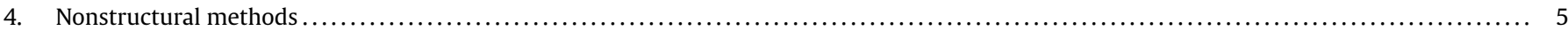

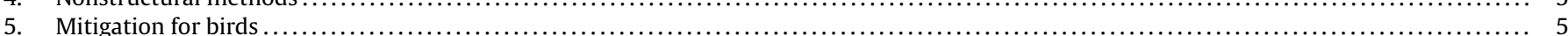

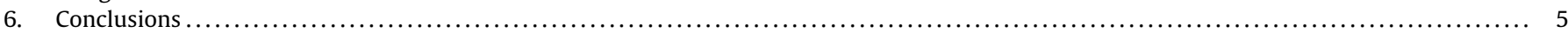

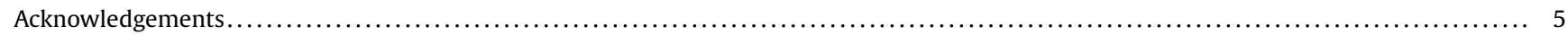

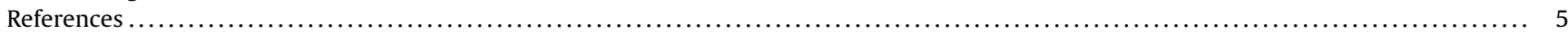

\section{Introduction}

Although roads provide some ecological benefits, such as maintenance of grassland plants in intense agricultural areas (Forman, 2000), they also can act as both physical and biological barriers to many wildlife species (Forman and Alexander, 1998; Jackson, 2000). Roads can affect the quality and quantity of available wildlife habitat, most notably through fragmentation. Likewise, vehicular traffic on roads can be direct sources of wildlife mortality, and in some instances, can be catastrophic to animal populations (Langton, 1989a). Many other ecological effects of roads on species,

\footnotetext{
* Corresponding author. Tel.: +1 315698 0940; fax: +1 3156980943.

E-mail address: Travis.L.DeVault@aphis.usda.gov (T.L. DeVault).
}

soils, and water have been identified, with effects varying in distance outward from meters to kilometers (Ellenberg et al., 1991; Forman, 1995). "Road-effect zones" impact an estimated 15-20\% of the land mass in the United States (Forman and Alexander, 1998).

Collisions with automobiles are a major source of direct mortality in some animal populations (Romin and Bissonette, 1996; Trombulak and Frissell, 2000; Gibbs and Shriver, 2002; Glista et al., 2008). Lalo (1987) estimated vertebrate mortality on roads in the United States at 1 million individuals per day. A variety of mitigation approaches are used to reduce the effects of roads and road mortality on wildlife populations. In general, these approaches fall into one of two categories: the modification of motorist behavior and/or the modification of animal behavior. Modification of motorist behavior often involves speed limits, lights, and signs, whereas modification of animal 
behavior often involves habitat alterations and/or installation of wildlife-crossing structures (Romin and Bissonette, 1996; Forman et al., 2003). Wildlife-crossing structures range from exclusion fences and culverts to overpass/underpass systems (Romin and Bissonette, 1996). Many structures are designed to reduce large animal-vehicle collisions (Forman et al., 2003). Such structures should be designed to allow safe passage for animals, promote habitat connectivity, be accessible, and encourage natural movements.

Unfortunately, the frequency at which road mortality mitigation measures are implemented does not correlate with their perceived effectiveness; the most promising measures often are the least used. For example, Romin and Bissonette (1996) reported that many U.S. states used wildlife-crossing signs and public awareness programs to reduce automobile collisions with large animals, although most state natural resource agencies admitted that the effectiveness of such measures was largely unknown to them. Conversely, relatively few U.S. states used fences, overpasses, and underpasses to reduce collisions, even though most agencies that used them reported that these structures were effective. Undoubtedly, economic factors often dictate the choice of road mortality mitigation measures that are implemented. Moreover, evaluations of mitigation success often are based on opinion rather than research (Forman et al., 2003). Poor road mortality mitigation designs do little to minimize road effects on wildlife and are generally a waste of time and money. Furthermore, poorly designed structures can interrupt natural processes that can lead to various ecological problems such as overgrazing, increased erosion, or population declines (Forman et al., 2003).

A growing literature in the field of road ecology suggests that vehicle/wildlife collisions can be major sources of vertebrate mortality and thus potentially limit wildlife populations (Aresco, 2005). For example, one recent study documented nearly 10,000 mortality events over 17 months at a single site (Glista et al., 2008). Mitigation measures that potentially reduce such collisions have been developed, and transportation officials should be aware of methods to reduce wildlife mortality on roadways. In this review, we summarize previous wildlife road mortality mitigation monitoring studies, describe some of the most common mitigation measures employed, and discuss factors that lead to the overall effectiveness of road mortality mitigation measures (Table 1 ).

\section{Types of crossing structures}

Pipe culverts are relatively small structures (0.3-2 m diameter) made of concrete, smooth steel, or corrugated metal designed to carry water under roads. Europe has led the way in implementing smaller pipe-style culverts, also referred to as "amphibian tunnels" (Forman et al., 2003; Fig. 1). Box culverts, generally larger than pipe culverts, also are used to allow water to pass under roads. Unlike pipe culverts, they usually remain dry except in periods of heavy runoff. Culverts may be used by a variety of wildlife species to cross roads (Yanes et al., 1995; Rodriguez et al., 1996; Clevenger and Waltho, 2000). Kaye et al. (2005) reported that spotted turtles (Clemmys guttata, a state threatened species) used a box culvert under a highway improvement project to move between two habitats in MA, United States. The use of a system consisting of a retaining well, box culverts, and pipe culverts reduced wildlife road mortality by $93.5 \%$ in the Paynes Prairie State Preserve, FL, United States (Dodd et al., 2004). Clevenger et al. (2001) monitored 36 culverts along the Trans-Canada highway and found a total of 618 crossings by a minimum of 9 species, with an average of 2.8 species at each culvert. In Australia, Taylor and Goldingay (2004) recorded 17 different vertebrate species

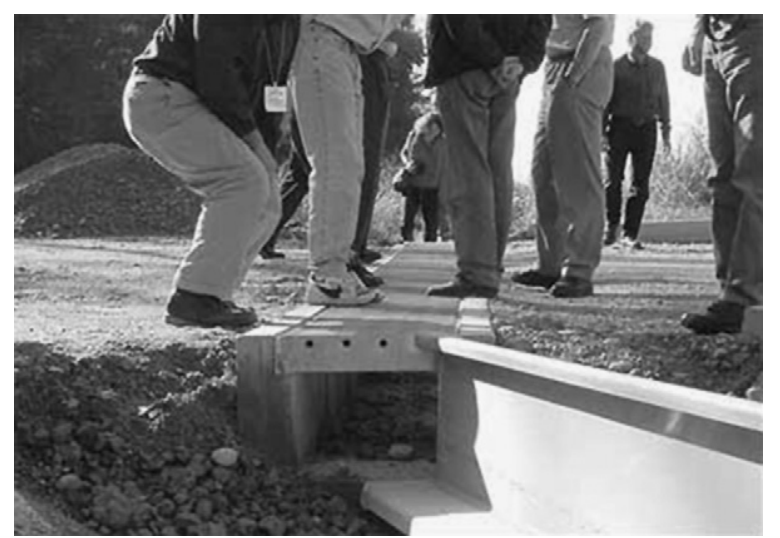

Fig. 1. Amphibian tunnel for mitigating road mortality (Federal Highway Administration, 2002).

using purpose-built fauna culverts in combination with exclusion fencing under the Pacific Highway. Of all wildlife-crossing structures, culverts may be one of the most economical. Furthermore, with some modification (e.g., the addition of drift fences, habitat modification at entrances, incorporation of dry ledges in culverts frequently inundated with water), preexisting culverts often may be used as crossings. A drawback to some culverts is that their size may not promote use by larger animals. Also, care must be taken to ensure that culverts remain open for animals to use.

Wildlife underpasses, also known as wildlife bridges, are large underpasses that provide a relatively unconfined passage for wildlife (Jackson and Griffin, 2000). Where roads cross over water or other roads, underpasses can provide a passageway for many wildlife species, especially those that use riparian corridors. In situations where underpasses hold excessive amounts of water, ledges can be incorporated into their designs to allow animal passage. Veenbaas and Brandjes (1999) reported that mammals used all (100\%) existing highway underpasses along waterways, and 75\% of underpasses were used by amphibians. Underpasses with the largest diameters were used most frequently by mammals; this relationship did not hold for amphibians. Passages with extended banks were used by more species overall. Some advantages to underpasses are that they can utilize natural terrain features to promote animal crossings and can accommodate a greater variety of species. Unfortunately, underpasses can be expensive due to construction costs, such as in instances where they must span large riparian areas.

Overpasses for wildlife are primarily designed for larger animals such as large carnivores and ungulates. They can range in width from 30 to $50 \mathrm{~m}$ to over $200 \mathrm{~m}$ on each end (Jackson and Griffin, 2000; Forman et al., 2003). Overpasses are sometimes referred to as "green bridges", a term used to describe wildlife overpasses with relatively large strips of natural vegetation crossing over roads (Bekker et al., 1995). "Landscape connectors" are especially wide overpasses that maintain the connectivity of horizontal ecological flows across the landscape (Forman et al., 1997). Wildlife overpasses accommodate a larger variety of species than do underpasses (Jackson and Griffin, 2000).

Van Wieren and Worm (2001) reported that a wildlife overpass in the central Netherlands was used frequently by large mammals, specifically red deer (Cervus elaphus) and wild boar (Sus scrofa). They also noted that animal crossings had increased almost threefold since previous monitoring in 1989 and suggested that the increase was due to habituation of red deer to the structure. Keller (1999) also noted that ungulates, most notably roe deer 
Table 1

Wildlife passage monitoring studies (modified from Forman et al., 2003).

\begin{tabular}{|c|c|c|c|c|c|}
\hline Study & Mitigation measure(s) & Location & Target species (or group) & Monitoring duration & Species encountered \\
\hline AMBS Consulting (1997) ${ }^{\mathrm{a}}$ & Underpasses & New South Wales, Australia & Unspecified & 9 months in 1997 & Unspecified \\
\hline Aresco (2005) & Drift fence and culverts & FL, USA & Reptiles and amphibians & April 2000-November 2003 & Reptiles and amphibians \\
\hline Ballon (1985) & Unspecified & Upper Rhine, France & Unspecified & 9 months in 1985 & Ungulates \\
\hline Cain et al. (2003) & Bridges and culverts & TX, USA & Bobcats & August 1997-May 1999 & Bobcats \\
\hline Clevenger $(1998)^{a}$ & Underpasses and overpasses & Alberta, Canada & Unspecified & January 1998-December 1998 & Large mammals \\
\hline Clevenger and Waltho (1999) & Dry drainage culverts & Alberta, Canada & $\begin{array}{l}\text { Small- and medium-sized } \\
\text { mammals }\end{array}$ & 74 days in late winter/early spring & Weasels \\
\hline Clevenger and Waltho $(2000)^{\mathrm{a}}$ & Underpasses and culverts & Alberta, Canada & Large mammals & $\begin{array}{l}\text { January 1995-March 1996, } \\
\text { November 1996-June } 1998\end{array}$ & Elk \\
\hline Clevenger and Waltho (2005) & Underpasses and overpasses & Alberta, Canada & Large mammals & November 1997-August 2000 & Deer \\
\hline Dodd et al. (2004) & Culverts & FL, USA & Unspecified & March 2001-March 2002 & Southern leopard frogs \\
\hline Donaldson (2005) & Underpasses & VA, USA & Large mammals & June 2004-May 2005 & White-tailed deer \\
\hline Fitzgibbon (2001) & Culverts & Vancouver, Canada & $\begin{array}{l}\text { Amphibians and small } \\
\text { mammals }\end{array}$ & 2000 & Weasels \\
\hline Foresman (2001) & Culverts & MT, USA & Small mammals & January 2001-August 2001 & Unspecified \\
\hline Foster and Humphrey (1995) & Underpasses & FL, USA & Florida panthers & 2 months, 16 days in 1995 & $\begin{array}{l}\text { Medium- to large-sized } \\
\text { mammals }\end{array}$ \\
\hline Hunt et al. $(1987)^{a}$ & Tunnels & New South Wales, Australia & Unspecified & 2 months in 1987 & $\begin{array}{l}\text { Small- to medium-sized } \\
\text { mammals }\end{array}$ \\
\hline Jackson (1996) & Amphibian tunnels & MA, USA & Spotted salamanders & Spring 1998 & Spotted salamanders \\
\hline Jackson and Tyning (1989) ${ }^{a}$ & Drift fences and tunnels & MA, USA & Spotted salamanders & 1988 & Spotted salamanders \\
\hline Jones (2000) & Reflectors, ramps, and pipes & Tasmania & $\begin{array}{l}\text { Eastern quolls, Tasmanian } \\
\text { devils }\end{array}$ & October 1990-April 1993 & Unspecified \\
\hline Kaye et al. (2005) & Culverts & MA, USA & Spotted turtles & April 2004-July 2004 & Unspecified \\
\hline Keller (1999) & Overpasses & $\begin{array}{l}\text { Switzerland, Germany, } \\
\text { France, and Netherlands }\end{array}$ & Unspecified & Unspecified & Roe deer \\
\hline Land and Lotz (1996) ${ }^{\mathrm{a}}$ & Underpasses & $\mathrm{FL}, \mathrm{USA}$ & Florida panthers & Unspecified & $\begin{array}{l}\text { Raccoons, white-tailed } \\
\text { deer }\end{array}$ \\
\hline Langton (2002) & Amphibian tunnels & England & Amphibians & Unspecified & Common toad \\
\hline LaPoint et al. (2003) & Various under-road passages & NY, USA & Unspecified & March 2002-April 2002 & Raccoons \\
\hline Lesbarreres et al. (2004) & Amphibian tunnels & France & $\begin{array}{l}\text { Common toad, water } \\
\text { frogs, agile frogs }\end{array}$ & February 2001-May 2001 & $\begin{array}{l}\text { Water frogs, common } \\
\text { toads }\end{array}$ \\
\hline Pfister et al. (1997) $)^{a}$ & Overpasses & $\begin{array}{l}\text { Switzerland, Germany, } \\
\text { France, Netherlands }\end{array}$ & Unspecified & 2 years & Mammals \\
\hline Puky and Vogel (2003) & Various types of passages & Hungary & Amphibians & Unspecified & Unspecified \\
\hline Reed et al. $(1975)^{\mathrm{a}}$ & Underpasses & WY, USA & Deer & 2 years & Ungulates \\
\hline Rodriguez et al. (1996)a & $\begin{array}{l}\text { Culverts, underpasses, and } \\
\text { overpasses }\end{array}$ & Montes de Toledo, Spain & None & September 1991-July 1992 & Small mammals \\
\hline Roof and Wooding (1996) a & Underpasses & FL, USA & Black bears & December 1994-December 1995 & Rabbits \\
\hline Rosell et al. $(1997)^{a}$ & Underpasses & Catalonia, Spain & Unspecified & 11 months in 1997 & Unspecified \\
\hline Taylor and Goldingay (2004) & Culverts & New South Wales, Australia & Unspecified & Spring/summer 2000 & Bandicoots \\
\hline Van Wieren and Worm (2001) & Overpasses & Netherlands & Mammals & 1989, 1994, 1995 & Red deer \\
\hline Veenbaas and Brandjes (1999)a & Various types of passages & Netherlands & Unspecified & Unspecified & Mice, voles \\
\hline Woods $(1990)^{\mathrm{a}}$ & Underpasses & Alberta, Canada & Unspecified & 3 years & Ungulates \\
\hline Yanes et al. (1995) ${ }^{\mathrm{a}}$ & Culverts & Central Spain & None & Four seasonal periods over 1 year & Small mammals \\
\hline
\end{tabular}

a Cited in Forman et al. (2003). 
(Capreolus capreolus), were the most frequent users of wildlife overpasses in Switzerland, Germany, France, and the Netherlands. At two overpass structures in Banff National Park, Canada, along the Trans-Canada Highway, Clevenger and Waltho (2005) reported that elk (Cervus elaphus) and deer (Odocoileus spp.) were large mammals that most frequently used the structures. Some advantages of overpasses are that they are less confining, quieter, maintain ambient conditions of rainfall, temperature, and light, and can serve as both passageways for wildlife and intermediate habitats for smaller animals (e.g., small mammals, reptiles, and amphibians) (Jackson and Griffin, 2000). One of the drawbacks of overpasses is that they often are the most expensive option due to their large size and construction costs.

\section{Factors influencing the effectiveness of crossing structures}

Several factors affect the ability of a crossing structure to facilitate wildlife movements. Location of crossing structures is very important and may be the most important factor predicting effectiveness (Podloucky, 1989; Foster and Humphrey, 1995; Yanes et al., 1995; Land and Lotz, 1996; Rodriguez et al., 1996; Clevenger and Waltho, 2000). Location is especially vital for smaller, less mobile species such as reptiles and amphibians (Jackson and Griffin, 2000). Rodriguez et al. (1996) suggested that crossing structures should be placed in areas of suitable habitat and that passages implemented near continual disturbance (e.g., excessive human presence) were less frequently used by several wildlife species (e.g., carnivores and ungulates).

The dimensions of structures are also important in designing passageways for vertebrates (Ulbrich, 1984; Ballon, 1985 [as cited in Yanes et al., 1995]). The size and shape of a particular structure may be the determining factor for crossing success (Reed et al., 1975; Ballon, 1985; Cain et al., 2003; Clevenger and Waltho, 2005). In Europe, hourglass-shaped overpasses are used regularly by wild boar, but not by red deer that become unnerved or frightened by the constriction at the center (Vassant et al., 1993 [as cited in Forman et al., 2003]). For some species, the relative openness in a passage may be more important than overall size (Foster and Humphrey, 1995; Clevenger and Waltho, 2005). Structures along the Trans-Canada Highway with high openness ratios (short in length, high and wide) were used most often by grizzly bears (Ursus arctos horribilis), wolves (Canis lupus), elk, and deer, whereas more constrictive structures were used more often by black bears (Ursus americanus) and cougars (Felis concolor) (Clevenger and Waltho, 2005). Tunnels that allow animals to see the other end were positively correlated with use by some species (Rosell et al., 1997 [as cited in Jackson and Griffin, 2000]). Conversely, some studies (Rodriguez et al., 1996; Clevenger and Waltho, 1999) have suggested that smaller passages may be better for some small mammals. There is some evidence that predators use crossing structures to increase prey capture (Hunt et al., 1987; Foster and Humphrey, 1995), which can limit the use of crossing structures by prey species. Culverts and underpasses that are exposed, restricted, or narrow may reduce the effectiveness of escape mechanisms of prey species (Reed et al., 1975; Yanes et al., 1995; Clevenger et al., 2001).

Approaches to structures also can affect their use by animals (Veenbaas and Brandjes, 1999; Clevenger and Waltho, 2000). The availability of cover (or lack thereof) at the approach to a crossing structure can determine whether a particular species will use it. Natural vegetation can enhance the "attractiveness" of crossing structures to animals and allow a continuity of habitat. Cover may influence the use of crossings by small to mid-sized mammals
(Hunt et al., 1987; Rodriguez et al., 1996; Clevenger and Waltho, 1999), but deter other species like deer and other ungulates if it restricts their vision (Pedevillano and Wright, 1987; Clevenger and Waltho, 2000).

The use of fencing and/or barrier walls in conjunction with passages can help prevent animal access to roads and facilitate movement of animals towards crossing structures (Ratcliffe, 1983; Feldhamer et al., 1986; Jackson and Tyning, 1989; Jackson, 1996; AMBS Consulting, 1997; Bissonette and Hammer, 2000; Jackson and Griffin, 2000; Dodd et al., 2004). A barrier wall in conjunction with a culvert system was effective in reducing wildlife road mortality 93.5\% in the Paynes Prairie State Preserve, Florida (Dodd et al., 2004). For many larger species, fencing is necessary because of their inherent avoidance of passages. Many ungulates avoid underpasses unless there is no other way to cross a road (Ward, 1982) and mountain lions traveling along streams are known to leave the stream and cross over highways rather than use under-road culverts (Beier, 1995). Fencing in the absence of crossing structures, however, can be detrimental, because it can act as a barrier to natural movements and contribute to habitat fragmentation (Jaeger and Fahrig, 2004). Fencing should extend far enough to either side of a crossing structure to promote guidance to the structure. The length of fencing often is dictated by the target species and the surrounding terrain. Because there is no universal design that works well for all roads, we recommend that transportation officials work with wildlife biologists to customize fencing regimes.

Moisture, temperature, light, substrate, and noise (disturbance) all can influence whether animals will use wildlife passages (Langton, 1989b; Mansergh and Scotts, 1989; Beier, 1995; Yanes et al., 1995; Jackson, 1996). Amphibians generally require moist conditions during migration, thus designing passages to allow rain to moisten the passage may be important (Jackson, 1996). Langton (1989b) reported that temperature differences between the interior and exterior of culverts may dissuade use by some amphibian species. The ability of air to flow freely through a passage (e.g., by using grate tops rather than solid tops) may help negate temperature differences and allow freer use by a wider range of species. Moreover, open tops will allow more ambient light to enter crossing structures. Jackson and Tyning (1989) noted that increased natural light in tunnels accelerated the rate at which spotted salamanders (Ambystoma maculatum) would cross. Conversely, artificial light often may deter animals from using a crossing structure (Reed, 1981; Jackson, 2000).

The inclusion of a natural substrate within a crossing structure can provide continuity of habitat and may encourage animals to pass (Yanes et al., 1995; Jackson, 2000). In controlled experiments between bare concrete tunnels, soil-lined tunnels, and open grass, Lesbarreres et al. (2004) found that water frogs (Rana esculenta) and common toads (Bufo bufo) preferred the tunnels to the grass, whereas agile frogs (Rana dalmatina) preferred grass. Use and crossing success were both higher in the soil-lined tunnel. Mougey (1996) suggested that frogs are deterred from bare concrete due to its alkalinity. Juvenile western toads (Bufo boreas) and red-legged frogs (Rana aurora) showed greater movement in culverts with substrate as opposed to culverts without (Bernard, 2000 [as cited in Fitzgibbon, 2001]).

Noise levels (e.g., traffic) can influence animal use of crossing structures (Clevenger and Waltho, 2000, 2005; Jackson, 2000). In Banff National Park, Canada, carnivore and ungulate movements through passages near the town of Banff were significantly affected by human activity and noise (Clevenger and Waltho, 2000). As such planners should consider the use of noise-reducing materials during construction of crossing structures. 


\section{Nonstructural methods}

Financial considerations are often a major concern when considering the implementation of wildlife road mortality mitigation measures. Cost can be extremely variable depending on the method chosen, availability of materials, and scale of the project. Usually, however, nonstructural methods are less expensive than structural methods. Bank et al. (2002) reported on a variety of nonstructural methods of road mortality mitigation currently being researched in Europe. These include: (1) olfactory repellents whereby scented foam is sprayed on vegetation and structures along the road, (2) ultrasound, (3) road lighting (which may have negative consequences for nesting birds), (4) population control (e.g., hunting), and (5) habitat modification, used primarily to keep animals away from roads or increase driver and animal visibility. Development of less expensive alternatives to expensive structures (e.g., overpasses) would allow wider use and promote permeability of road corridors (Forman et al., 2003). Biological consequences of nonstructural methods are not well understood, and more research is needed to ascertain their effectiveness.

Although it is impossible to predict exactly where and when animals will appear on roads, motorists who are aware of the potential for animal crossings can sometimes help mitigate wildlife road mortality. The use of signs and/or speed bumps to reduce speed and enhancing speed limit enforcement may help reduce road mortality of wildlife in areas of known animal crossings. High-speed traffic is often considered one of the main causes of wildlife-vehicle collisions (Pojar et al., 1975; Case, 1978). Wildlifecrossing signs also can be installed in areas of intense animal activity to help make drivers more aware of wildlife presence, although their effectiveness is questionable (Pojar et al., 1975; Aberg, 1981 [as cited in Groot Briunderink and Hazebroek, 1996]). Even stuffed mule deer (Odocoileus hemionus) placed in road rights-of-way failed to evoke a reaction from many drivers (D.F. Reed, personal communication [as cited in Groot Briunderink and Hazebroek, 1996]), suggesting that traffic control is one of the most difficult options in wildlife road mortality mitigation.

\section{Mitigation for birds}

Although most wildlife road mortality mitigation measures focus on mammals, reptiles, and amphibians, roads also can affect birds through fragmentation, isolation, and direct mortality. Although most birds possess the ability to fly over roads rather than walk or run across them, they also have some unique problems. Birds often define territories by the use of songs, and if those songs cannot be heard over (or are distorted by) vehicular traffic noise, males may find it difficult to attract and keep mates (Ferris, 1979; Reijnen et al., 1995). Traffic noise could potentially force males to conduct wider searches for females and bring them closer to roads. Many migrating species rely on starlight navigation (Emlen, 1975), thus light pollution from a variety of sources, including highway lighting, may cause birds to become disoriented, resulting in collisions with automobiles (Ogden and Evans, 1996). Non- or low-flying birds (e.g., quail, turkeys, owls), birds that forage at ground level, and scavengers are even more susceptible to road mortality because of their habits (Stoner, 1925). Therefore, birds present several road mortality mitigation challenges compared to other vertebrates. Jacobson (2005) addressed several of these problems and suggested possible solutions, including the reduction of noise and light pollution.

\section{Conclusions}

Everyone (transportation officials, wildlife biologists, the general populace) can agree that collisions between vehicles and wildlife are undesirable. Unfortunately, the reduction of such collisions is difficult and nuanced because of many factors, including economics, human attitudes, and wildlife biology. The inherent problem when designing effective wildlife-crossing structures concerns the need to accommodate high priority species while maintaining an economic and structurally sound building plan. When possible, target sites for road mortality mitigation should be identified a priori in consultation with transportation planners and wildlife biologists, but more often are identified $a$ posteriori. Either way, mitigation approaches usually are targeted for a particular species or group of organisms. Although many studies have reported on the use of various structures for reducing road mortality, relatively few have measured the success of such structures. As such, more research is needed concerning the effectiveness of various road mortality mitigation programs. Although specific recommendations are best made in consultations among planners, engineers, and local biologists, we provide below some general recommendations regarding wildlife collision reduction:

(1) Preconstruction planning is generally more economical than retrofitting existing roads and potentially could be considered during environmental impact assessments.

(2) Connectivity of habitat and permeability of road systems are important factors.

(3) Financial considerations may dictate nonstructural approaches to collision reduction, but structural methods are probably more effective (and more expensive).

(4) Finally, the efficiency of road mortality mitigation approaches should be determined via a post-implementation monitoring program.

\section{Acknowledgements}

We would like to thank the Joint Transportation Research Program of the Indiana Department of Transportation and Purdue University for funding our research. We also would like to thank O.E. Rhodes, Jr. and H.P. Weeks for their reviews of earlier versions of the manuscript.

\section{References}

Aberg, L., 1981. The human factor in game-vehicle accidents: a study of driver's information acquisition. Acta Universitatis Upsalienis, Studia Psychologica Upsaliensia 6, Uppsala, Finland.

AMBS Consulting, 1997. Fauna usage of three underpasses beneath the F3 freeway between Sydney and Newcastle. Final report to New South Wales Roads and Traffic Authority, Sydney, Australia.

Aresco, M.J., 2005. Mitigation measures to reduce highway mortality of turtles and other herpetofauna at a north Florida lake. Journal of Wildlife Management 69, 549-560.

Ballon, P., 1985. Premieres observations sur l'efficacite des passages a gibier sur l'autoroute A36. In: Routes et faune sauvage. Service d'Etudes Techniques de Routes et Autoroutes, Bagneaux, France, pp. 311-316.

Bank, F.G., Irwin, C.L., Evink, G.L., Gray, M.E., Hagood, S., Kinar, J.R., Levy, A., Paulson, D., Ruediger, B., Sauvajot, R.M., Scott, D.J., White, P., 2002. Wildlife habitat connectivity across European highways. Technical Report FWHA-PL-02-011. U.S. Department of Transportation, Washington, DC.

Beier, P., 1995. Dispersal of juvenile cougars in fragmented habitat. Journal of Wildlife Management 59, 228-237.

Bekker, H., van den Hengel, B., van Bohemen, H., van der Sluijs, H., 1995. Natuur over wegen. Ministry of Transport, Public Works and Water Management, Delft, Netherlands.

Bernard, D., 2000. Unpublished environmental monitor's report submitted to the Vancouver Island highway project. Ministry of Transportation and Highways. Victoria, British Columbia, Canada.

Bissonette, J., Hammer, M., 2000. Comparing the effectiveness of earthen escape ramps with one-way gates in Utah. Unpublished. USGS Utah cooperative Fish 
and Wildlife Research Unit, Department of Fisheries and Wildlife, College of Natural Resources, Utah State University, Logan, UT.

Cain, A.T., Tuovila, V.R., Hewitt, D.G., Tewes, M.E., 2003. Effects of a highway and mitigation projects on bobcats in southern Texas. Biological Conservation 114, 189-197.

Case, R.M., 1978. Interstate highway road-killed animals: a data source for biologists. Wildlife Society Bulletin 6, 8-13.

Clevenger, A.P., 1998. Permeability of the Trans-Canada highway to wildlife in Banff National Park: importance of crossing structures and factors influencing their effectiveness. In: Evink, G.L., Garrett, P., Zeigler, D., Berry, J. (Eds.), Proceedings of the International Conference on Wildlife Ecology and Transportation. FL-ER69-98. Florida Department of Transportation, Tallahassee, FL, pp. 109-119.

Clevenger, A.P., Chruszcz, B., Gunson, K., 2001. Drainage culverts as habitat linkages and factors affecting passage by mammals. Journal of Applied Ecology 38, $1340-1349$.

Clevenger, A.P., Waltho, N., 1999. Dry drainage culvert use and design considerations for small- and medium-sized mammal movement across a major transportation corridor. In: Evink, G.L., Garrett, P., Zeigler, D., Berry, J. (Eds.), Proceedings of the International Conference on Wildlife Ecology and Transportation. FL-ER-69-98. Florida Department of Transportation, Tallahassee, FL, pp. 263-277.

Clevenger, A.P., Waltho, N., 2000. Factors influencing the effectiveness of wildlife underpasses in Banff National Park, Alberta, Canada. Conservation Biology 14, 47-56.

Clevenger, A.P., Waltho, N., 2005. Performance indices to identify attributes of highway crossing structures facilitating movement of large mammals. Biological Conservation 121, 453-464.

Dodd Jr., C.K., Barichivich, W.J., Smith, L.L., 2004. Effectiveness of a barrier wall and culverts in reducing wildlife mortality on a heavily traveled highway in Florida. Biological Conservation 118, 619-631.

Donaldson, B.M., 2005. Use of highway underpasses by large mammals and other wildlife in Virginia and factors influencing their effectiveness. In: Proceedings of the International Conference of Ecology and Transportation, San Diego, CA, pp. 433-441.

Ellenberg, H., Muller, K., Stottele, T., 1991. Strassen-Okologie. In: Okologie und strasse. Broschurenreihe de Deutschen Strassenliga, Bonn, Germany, pp. 19-115.

Emlen, S.T., 1975. Migration: orientation and navigation. In: Farmer, D.S., King, J.R. (Eds.), Avian Biology, vol. 5. Academic Press, New York, pp. 129-219.

Federal Highway Administration, 2002. FHWA website. http://www.fhwa.dot.gov/ environment/greenerroadsides/sum02p3.htm.

Feldhamer, G.A., Gates, J.E., Harman, D.M., Loranger, A.J., Dixon, K.R., 1986. Effects of interstate highway fencing on white-tailed deer activity. Journal of Wildlife Management 50, 497-503.

Ferris, C.R., 1979. Effects of Interstate 95 on breeding birds in northern Maine. Journal of Wildlife Management 43, 421-427.

Fitzgibbon, K., 2001. An evaluation of corrugated steel culverts as transit corridors for amphibians and small mammals at two Vancouver Island wetlands and comparative culvert trials. Thesis, Royal Roads University, Vancouver, British Columbia, Canada.

Foresman, K.R., 2001. Small mammal use of modified culverts on the Lolo South project of western Montana. In: Proceedings of the International Conference of Ecology and Transportation, Keystone, CO.

Forman, R.T.T., 1995. Land Mosaics: The Ecology of Landscapes and Regions. Cambridge University Press, Cambridge, United Kingdom.

Forman, R.T.T., 2000. Estimate of the area affected ecologically by the road system in the United States. Conservation Biology 14, 31-35.

Forman, R.T.T., Alexander, L.E., 1998. Roads and their major ecological effects. Annual Review of Ecology and Systematics 29, 207-231.

Forman, R.T.T., Freidman, D.S., Fitzhenry, D., Martin, J.D., Chen, A.S., Alexander, L.E., 1997. Ecological effects of roads: toward three summary indices and an overview for North America. In: Canters, K. (Ed.), Habitat Fragmentation and Infrastructure. Ministry of Transport, Public Works and Water Management, Delft, Netherlands, pp. 40-54

Forman, R.T.T., Sperling, D., Bissonette, J.A., Clevenger, A.P., Cutshall, C.D., Dale, V.H., Fahrig, L., France, R., Goldman, C.R., Heanue, K., Jones, J.A., Swanson, F.J., Turrentine, T., Winter, T.C., 2003. Road Ecology; Science and Solutions. Island Press, Washington DC.

Foster, M.L., Humphrey, S.R., 1995. Use of highway underpasses by Florida panthers and other wildlife. Wildlife Society Bulletin 23, 95-100.

Gibbs, J.P., Shriver, G., 2002. Estimating the effects of road mortality on turtle populations. Conservation Biology 16, 1647-1652.

Glista, D.J., DeVault, T.L., DeWoody, J.A., 2008. Vertebrate road mortality predominately impacts amphibians. Herpetological Conservation and Biology 3, $77-87$.

Groot Briunderink, G.W.T.A., Hazebroek, E., 1996. Ungulate traffic collisions in Europe. Conservation Biology 10, 1059-1067.

Hunt, A., Dickens, J., Whelan, R.J., 1987. Movement of mammals through tunnels under railway lines. Australian Zoologist 24, 89-93.

Jackson, S.D., 1996. Underpass systems for amphibians. In: Evink, G.L., Garrett, P., Zeigler, D., Berry, J. (Eds.), Proceedings of the International Conference on Wildlife Ecology and Transportation. FL-ER-69-98. Florida Department of Transportation, Tallahassee, FL, pp. 240-244

Jackson, S.D., 2000. Overview of transportation related wildlife problems. In: Evink, G.L., Garrett, P., Zeigler, D., Berry, J. (Eds.), Proceedings of the International Conference on Wildlife Ecology and Transportation. FL-ER-69-98. Florida Department of Transportation, Tallahassee, FL, pp. 1-4.
Jackson, S.D., Griffin, C.R., 2000. A strategy for mitigating highway impacts on wildlife. In: Messmer, T.A., West, B. (Eds.), Wildlife and Highways: Seeking Solutions to an Ecological and Socio-economic Dilemma. The Wildlife Society, Bethesda, MD, pp. 143-159.

Jackson, S.D., Tyning, T.F., 1989. Effectiveness of drift fences and tunnels for moving spotted salamanders Ambystoma maculatum under roads. In: Langton, T.E.S (Ed.), Amphibians and Roads, Proceedings of the Toad Tunnel Conference. ACO Polymer Products Ltd., Bedfordshire, England, pp. 93-99.

Jacobson, S.L., 2005. Mitigation measures for highway-caused impacts to birds. PSWGTR-191. USDA Forest Service General Technical Report.

Jaeger, J.A.G., Fahrig, L., 2004. Effects of road fencing on population persistence. Conservation Biology 18, 1651-1657.

Jones, M., 2000. Road upgrade, road mortality, and remedial measures: impacts on a population of eastern quolls and Tasmanian devils. Wildlife Research 27 289-296.

Kaye, D.R., Walsh, K.M., Ross, C.C., 2005. Spotted turtle use of a culvert under relocated Route 44 in Carver, Massachusetts. In: Proceedings of the International Conference of Ecology and Transportation, San Diego, CA, pp. 426-432.

Keller, V., 1999. The use of wildlife overpasses by mammals: results from infrared video surveys in Switzerland, Germany, France, and the Netherlands. In: Proceedings of the 5th Infra Eco Network Europe conference, Budapest, Hungary.

Lalo, J., 1987. The problem of roadkill. American Forests 50, 50-52.

Land, D., Lotz, M., 1996. Wildlife crossing designs and use by Florida panthers and other wildlife in Southwest Florida. In: Evink, G.L., Garrett, P., Zeigler, D., Berry, J. (Eds.), Proceedings of the International Conference on Wildlife Ecology and Transportation. FL-ER-69-98. Florida Department of Transportation, Tallahassee, FL, pp. 323-328.

Langton, T.E.S., 1989a. Reasons for preventing amphibian mortality on roads. In: Langton, T.E.S. (Ed.), Amphibians and Roads, Proceedings of the Toad Tunnel Conference. ACO Polymer Products Ltd., Bedfordshire, England.

Langton, T.E.S., 1989b. Tunnels and temperature: results from a study of a drift fence and tunnel system at Henley-on-Thames, Buckinghamshire, England. In Langton, T.E.S. (Ed.), Amphibians and Roads, Proceedings of the Toad Tunnel Conference. ACO Polymer Products Ltd., Bedfordshire, England.

Langton, T.E.S., 2002. Measures to protect amphibians and reptiles from road traffic In: Sherwood, B., Cutler, D., Burton, J. (Eds.), Wildlife and Roads: The Ecological Impact. Imperial College Press, London, England, pp. 223-248.

LaPoint, S.D., Kays, R.W., Ray, J.C., 2003. Animals crossing the Northway: are existing culverts useful? Adirondack Journal of Environmental Studies Spring/Summer, $11-17$.

Lesbarreres, D., Lode, T., Merila, J., 2004. Short communication: what type of amphibian tunnel could reduce road kills? Oryx 38, 220-223.

Mansergh, I.M., Scotts, D.J., 1989. Habitat continuity and social organization of the mountain pygmy-possum restored by tunnel. Journal of Wildlife Management 53, 701-707.

Mougey, T., 1996. Des tunnels pour batraciens. Le Courier de la Nature 155, 22-28.

Ogden, L., Evans J., 1996. Collision course: the hazards of lighted structures and windows to migrating birds. Report published by World Wildlife Fund Canada and Fatal Light Awareness Program.

Pedevillano, C., Wright, R.G., 1987. The influence of visitors on mountain goat activities in Glacier National Park, Montana. Biological Conservation 39, 1-11.

Pfister, H.P., Keller, V., Reck, H., Georgii, B., 1997. Bio-Ecological Effectiveness of Wildlife Overpasses or "Green Bridges" Over Roads and Railway Lines. Herausgegeben vom Bundesministerium fur Verkehr Abeteilung Strassenbau. Bonn-Bad Godesberg, Germany.

Podloucky, R., 1989. Protection of amphibians on roads: examples and experiences from Lower Saxony. In: Langton, T.E.S. (Ed.), Amphibians and Roads, Proceedings of the Toad Tunnel Conference. ACO Polymer Products Ltd., Bedfordshire, England, pp. 15-28.

Pojar, T.M., Prosence, R.A., Reed, D.F., Woodard, T.N., 1975. Effectiveness of a lighted, animated deer crossing sign. Journal of Wildlife Management 39, 87-91.

Puky, M., Vogel, Z., 2003. Amphibian mitigation measures on Hungarian roads: design, efficiency, problems, and possible improvement, need for a coordinated European environmental education strategy. Habitat fragmentation due to transportation infrastructure. In: Proceedings of the 9th Infra Eco Network Europe conference, Brussels, Belgium.

Ratcliffe, J., 1983. Why did the toad cross the road? Wildlife August, 304-307.

Reed, D.F., 1981. Mule deer behavior at a highway underpass exit. Journal of Wildlife Management 45, 542-543.

Reed, D.F., Woodard, T.N., Pojar, T.M., 1975. Behavioral response of mule deer to a highway underpass. Journal of Wildlife Management 39, 361-367.

Reijnen, R., Foppen, R., Braak, C.T., Thissen, J., 1995. The effects of car traffic on breeding bird populations in woodland. III. Reductions of density in relation to proximity of main roads. Journal of Applied Ecology 32, 187-202.

Rodriguez, A., Crema, G., Delibes, M., 1996. Use of non-wildlife passages across a high-speed railway by terrestrial vertebrates. Journal of Applied Ecology 33 , $1527-1540$.

Romin, L.A., Bissonette, J.A., 1996. Deer-vehicle collisions: status of state monitoring activities and mitigation efforts. Wildlife Society Bulletin $24,276-283$.

Roof, J., Wooding, J., 1996. Evaluation of the S.R. 46 wildlife crossing in Lake County, Florida. In: Evink, G.L., Garrett, P., Zeigler, D., Berry, J. (Eds.) Proceedings of the International Conference on Wildlife Ecology and Transportation. FL-ER-69-98. Florida Department of Transportation, Tallahassee, FL, pp. 329-336. 
Rosell, C., Parpal, J., Campeny, R., Jove, S., Pasquina, A., Velasco, J.M., 1997. Mitigation of barrier effect of linear infrastructures on wildlife. In: Canters, K. (Ed.), Habitat Fragmentation and Infrastructure. Ministry of Transport, Public Works and Water Management, Delft, Netherlands, pp. 367-372.

Stoner, D., 1925. The toll of the automobile. Science 61, 56-57.

Taylor, B.D., Goldingay, R.L., 2004. Wildlife road-kills on three major roads in northeastern New South Wales. Wildlife Research 31, 83-91.

Trombulak, S.C., Frissell, C.A., 2000. Review of ecological effects of roads on terrestrial and aquatic communities. Conservation Biology 14, 18-30.

Ulbrich, P., 1984. Untersuchung der wirksamkeit von wildwarnreflektoren und der eignung von wilddurchschlassen. Zeitschrift Fur Jagdwissenschaft 30 101-116.

Van Wieren, S.E., Worm, P.B., 2001. The use of a motorway wildlife overpass by large mammals. Netherlands Journal of Zoology 51, 97-105.
Vassant, J., Brandt, S., Jullien, J.M., 1993. Influence du passage de l'autoroute A5 sur les populations cert et sanglier du Massif d'Arc-en-Banois: 1er partie. Bulletin de l'Office National de la Chasse 183, 15-25.

Veenbaas, G., Brandjes, J., 1999. Use of fauna passages along waterways under highways. In: Evink, G.L., Garrett, P., Zeigler, D., Berry, J. (Eds.), Proceedings of the International Conference on Wildlife Ecology and Transportation. FL-ER-69-98. Florida Department of Transportation, Tallahassee, FL, pp. 253-258.

Ward, A.L., 1982. Mule deer behavior in relation to fencing and underpasses on Interstate 80 in Wyoming. Transportation Research Record 859, 8-13.

Woods, J.G., 1990. Effectiveness of fences and underpasses on the Trans-Canada Highway and their impact on ungulate populations. Report to Banff National Park Warden Service. Banff, Alberta, Canada.

Yanes, M., Velasco, J., Suarez, F., 1995. Permeability of roads and railways to vertebrates: the importance of culverts. Biological Conservation 71, 217-222. 